Research Paper

\title{
Count Them in! Inclusion of Persons with Disabilities in a Diversified Workforce - A Transformative Mixed-methods Study
}

\author{
Edmon Yumul Sampana \\ Graduate School, Centro Escolar University \\ Manila, Philippines \\ Corresponding author: sampana1615105@ceu.edu.ph \\ Ambrosio De la Cruz \\ Graduate School, Centro Escolar University \\ Manila, Philippines
}

\section{About the authors}

Prof. Edmon Y. Sampana is currently working with Mabalacat City College, Pampanga, Philippines, as a member of the teaching department. He is presently taking his Ph.D course study in Psychology at Centro Escolar University, Manila. He is a licensed professional teacher with National Certification III (NC III) in Events Management, and a holder of Trainer's Methodology 1 (TM1) regulated by the Technical Education and Skills Development Authority.

Dr. Ambrosio De la Cruz is currently teaching as a part time professor in the graduate school of Centro Escolar University, Manila, Philippines. He is the President and CEO of AHRMDCO INTERNATIONAL, which provides competency-based training programs and consultancy services. He is a certified Industrial and Organizational Specialist and Trainer uplifting skills and techniques to improve job competencies and key behavioral indicators in the organization.

\section{Abstract}

Employment is considered a critical element of independent living, most notably for Persons with Disabilities (PWDs). In the context of work, it is a gateway to further showcase their talents, skills and other capabilities as part of the nation building and catalyst of significant change. This study aims to gather significant inputs from organizations in the context of hiring, retention, practical and policy strategies towards the formulation of hiring and retaining action plans for PWDs. The research design is sequential-transformativemixed methods. Data were gathered through surveys, interviews, and focused group discussions by using a validated tool and a questionnaire. Purposive sampling method was utilized. Participants are in the 
Philippines in Central Luzon, Region III, Philippines who have first-hand engagement in the employment of PWDs. Researchers consulted 98 organizations with 161 employed PWDs. Descriptive and correlational

statistics were processed. Qualitative data underwent data analysis. Results are presented in terms of their willingness to express agreement in the hiring and retaining of PWDs, and the willingness to rate the practical strategies and policies regarding the hiring and retaining of PWDs. The findings of this study show a significant relationship among the type of disabilities (visual, auditory, orthopedic and psychosocial disabilities) of working PWDs, the number of organizations with PWDs per province, the nature of the working environment and their job titles. However, there is very limited relationship between their type of disabilities and the categories of white collar, blue collar and pink collar. The barriers to this include the lack of awareness of the managers, the inclusivity policy of the institutions, the incompetency amongst PWDs, the relatively high employment cost, and the loss of productivity. Potential solutions are financial support and subsidies, capability building, enhancement of the partnership between the industry and government sectors, and improvement of the existing non-discrimination laws.

Keywords: Workplace Diversity, Inclusion and Accommodation, Persons with Disabilities $(P W D s)$, Hiring, Retention

\section{Introduction}

Workplace diversity refers to the variety of differences between individuals in an organization. It does not only suggest how individuals identify themselves but also how others perceive them. It encompasses information regarding the employee' race, gender, ethnic group, age, religious affiliation, sexual orientation, citizenship status, military service, mental and physical condition, as well as other distinct differences from people (Dyson, 2017). Indeed, it seems that managing a diversified workforce is an inevitable challenge nowadays for organizations. For the upcoming years, industries that pay much more attention to the issue of managing a diversified workforce will serve as a competitive advantage and avenue towards multifaceted platforms for further growth and development (Talent Intelligence, 2014). This study hopes to provide significant insights to acknowledge better the participation of PWDs in building the nation, especially within the context of revolutionizing the economy through the catalyst of change for success towards profitability and growth. Persons with Disabilities (PWDs) refer to individuals who suffer from long-term physical, mental, intellectual or sensory impairments. Upon interaction, the various barriers may hinder their full and active participation in social activities. According to the International Classification of Functioning, Disability and Health (ICF) of the World Health Organization (WHO), disability is a complex concept with multiple dimensions. It connotes activity limitations and participation restrictions referring to the negative aspects of the interaction between an individual having health conditions and the individual's environmental and personal factors (International Labour Organization, 2014). Working with PWDs creates a magnitude of benefits for industries such as improving job morale and corporate culture. In addition, it can also increase consumer market revenue, help reduce employee turnover, and have a positive influence on those enduring lesser conflict (Perriello, 2015). Organizational platforms must now be open to all people, especially to those 
who are often neglected and abandoned like PWDs due to continuous stereotyped discrimination (Manila Bulletin, 2014).

The principle of inclusion of PWDs at the workplace will be a good start to break the said mantle of discrimination. Inclusion is the achievement of a work environment in which all individuals are treated fairly and respectfully. They should have equal access to opportunities and resources so they can contribute fully to the organization's success (Talent Intelligence, 2014). Inclusivity of PWDs at the workplace is always an issue even up to this point of time due to the fact that industries nowadays are still occupied with many fears, such as the fear that PWDs lack necessary skills, abilities, and other significant characteristics, the fear of litigation associated with terminating PWDs, the fear of lower productivity and higher costs (Unger, 2002). In addition, people with disabilities have lower employment rates than persons without disabilities in developing countries (Mizunoya and Mitra, 2013). For instance, here in the Philippines, based on the column of Imperial (2017) in the cover issue of VERA Files, $85 \%$ of the 1.4 million Filipino PWDs still receive unfair treatment in the context of work (Philippine Statistics Authority, 2010). Definitely, there remain lots of things to weigh and consider for the aforementioned fears and gaps to be removed with

the inclusion of PWDs at workplaces. Continued research is needed to better understand how each of these factors contributes to heightened employment equity and opportunity for individuals with disabilities (Bruyere et al., 2004). Schools, industries, government, non-government sectors, and PWDs themselves must work together towards the formulation of policies and programs that will all, in the end, benefit especially the vulnerable ones, PWDs.

\section{Theoretical Framework}

This study, which concerns the inclusion of persons with disabilities as part of a diversified workforce, encompasses and values the approaches proposed by Thomas and Ely (1996) for the macro-level (organizational level) and Dietz \& Petersen (2006) for the micro-level (individual employee). The said approaches in managing an organization emanated from the social-identity theory of Tajfel (1978) and self-categorization theory of Turner (1999), respectively. The social-identity theory describes a sense of identification and belongingness of a person's membership, and his behavior within a group, while the self-categorization theory describes the process of people categorization in group terms or within the context of large group components to produce an array of behaviors with no regard to membership, conformity, or stereotyping (Trepte and Loy, 2017). At the macro level which is also interpreted as the organizational level of business, the goal here is to reasonably limit the relationship between workplace diversity and performance through observation. Thomas and Ely's model (1996), to its great extent, produces three types of perspectives in managing diversity at the macro level, i.e., discrimination-and-fairness, access-and-legitimacy, and integration-and-learning. Thomas and Ely (1996) found that integration-and-learning is the best and has a larger contributory impact than the other two on inter-group positivity, feelings of being valued and respected, and employees' attitude on the racial identity issue at the workplace. The micro-level theory or the individual-employee level theory, on the other hand, is based on the understanding of dynamics in handling issues related to stereotypes, prejudices, and 
discrimination at the workplace (Dietz \& Petersen, 2006). Advocates of the micro-level theory do justify and believe that prejudices and stereotypes are forerunners of discrimination. This means that discrimination is a product generated by a culture of continuous prejudices and stereotypes. Dietz and Petersen (2006) also added that other factors must be taken into account in order to eliminate discrimination at the workplace, such as the development of social identities and categorizations, group conflicts, and contact with persons with demographical and further individual differences.

In addition, researchers also considered that the inputs of diversity and inclusion are the key ingredients to have a highly productive, creative, and innovative workforce. Progressive organizations do not exist without diversity inclusion. They work on the issue to develop and execute "people strategies" that focus not only on recruiting, hiring and retaining a diverse workforce. Employees, who feel welcomed, valued, respected, and supported by their co-workers and managers, not only produce better work, but enjoy more satisfying personal lives as well. Because work and personal lives are intertwined, any imbalance between the two can potentially affect an employee's ability to fully engage in the job and achieve the goals of the company. A diverse, engaged, and motivated workforce is essential to both a healthy bottom line and a strong competitive advantage in the marketplace (Hicks, 2017).

This study is grounded on the macro and micro models proposed by Thomas and Ely (1996) and Dietz \& Petersen (2006) together with the concepts mentioned above. The diverse and inclusion issue in workplaces is discussed within the bounds of the various organizational levels. PWDs are the paramount concern of the researchers because they are prone to discrimination at workplaces. Therefore, it is imperative that this factor should be looked into towards workplace inclusivity (Levosada, 2017; Mina, 2013). Retaining and developing employees in a creative, diverse, and inclusive work environment will result in the empowerment and growth towards individual and organizational successes (Bruyere et al., 2004). In order to make these things possible, further consultations and an in-depth understanding on PWDs' workplace inclusivity are needed, especially with those organizations (profit and non-profit) which have first-hand employment engagement and accommodation of PWDs. By gathering data from different organizations, significant inputs and findings are expected to formulate a decisive plan and enact strategies and policies for the improvement of this issue.

\section{Previous Study on the Issue}

Previous study demonstrates a well-developed set of ideas and interests on this issue. These articles give hints to our research about current situation in the Philippines.

In a review article by Saxena (2014), the impact of diversity on productivity is also analyzed and assessed. The researcher concluded that although workforce diversity is strength in an organization, challenges remained due to the stereotyped views about PWDs, such as their being inefficient and ineffective, and the compromise of productivity. Dike (2013) examined five companies in Finland and Ghana which managed a diversified workforce and analyzed the challenges that employees have to face in maintaining and developing the competitiveness of the companies within a culturally diverse context. The result shows that workplace 
diversity plays an effective role in promoting the productivity. However, it may have a negative effect if mentoring and guidance is not inadequate. Through comparison between big and small companies, it is discovered that big companies are more passionate in dealing with workplace diversity while small companies do have difficulty in effectively managing the issue. Levosada (2017), pertaining to the PWDs employment issue, reiterated that as provided in the law of the Philippines, equal employment opportunity shall be given to PWDs in the selection process based on the qualification standards of positions in government and the requirements set by the employers in private corporations. Moreover, PWDs shall also be subject to the same terms and conditions of employment, compensation, privileges, benefits, incentives or allowances as an able-bodied person. In addition, accommodation of PWDs should not impose undue or disproportionate burden on them but must ensure equal opportunity in all fundamental rights.

Sellevol (2016) investigated the experiences of disabled people in the job-seeking process. His study sample consists of seven PWDs and one employer within the framework of a social model of disability. The social understanding of disability offers only a little room for PWDs to be hired. PWDs desire to be treated as ordinary workers without special adaptations in regard to the responsibilities and benefits of the job position. This has prevented the PWDs from obtaining chances in job-seeking.

Kaye, Jans and Jones (2011) interviewed human resource professionals and supervisors working for employers who are known for being reluctant to comply with the government's employment provisions. They were asked to provide various possible reasons that employers might not hire, retain, or accommodate PWDs, and to rate the strategy and policy changes that might make it more likely for employers to fulfill this duty. Results show that the important factors related to this are lack of awareness of disability and accommodation issues, concern about extra costs, and fear of legal liability. Intensified training on the accommodation expertise and mechanisms of PWDs were identified as an effective strategy to increase hiring and retaining. Preferred public policy approaches include no-cost external problem-solving, subsidized accommodations, tax breaks, and mediation in lieu of formal complaints or lawsuits.

Tacadao and Narido (2016) studied the employment profile of PWDs in selected regions in the Philippines in their working paper. The 150 respondents were selected and surveyed on their profile such as employment, sources of income, trainings acquired, and job search experiences. The key findings are as follows:

(a) The leading occupations among PWDs are within the sectors of health professionals and jobs with elementary operations, as well as in clerical works;

(b) Education and training are critical factors for their success in getting a satisfactory job;

(c) PWDs rely on their friends and families in job-seeking;

(d) There are companies that mainstream the employment of PWDs;

(e) Government organizations play an important role in promoting the inclusion of PWDs at the workplace;

(f) There is a notable need to strictly implement laws and policies regarding PWDs' inclusion and employment.

Colella and Bruyère (2011) mentioned that in terms of employment and participation on the labor market, 
PWDs are still the underemployed workforce group and even viewed as disadvantaged (International Labour Organization, 2014). Considering the population of PWDs seeking for work, there is only a small portion who are finally able to land on regular jobs. Finding a decent job is still a struggle for PWDs taking into account of the physical limitations and medical conditions. Some PWDs still depend on the support of their families rather than the assistance from the government (Quilalang, 2019). Most organizations have not realized that PWDs do have potentials. They could be an asset for their development. Their talents, capacity, and experience can also lead the organization to become excellent employees benefitting from the growth and productivity of the entire organization in the end. In all, organizations must ensure to exercise equal employment opportunity for PWDs with all its fundamental rights (Levosada, 2017).

\section{Statement of the Problem}

Managing a diversified workforce is a big issue. But as long as there is an open chance of modification to systems and policies, a magnitude of significant benefits will eventually be created for organizations. Dike (2013) stressed that fair and just treatment in managing diversity will lead to a revolutionized productivity. Inclusion of PWDs is a good start to further meet the challenge of inevitable diversity at the workplace. PWDs must be offered the same terms and conditions of employment, compensation, privileges and benefits like an able-bodied person (Levosada, 2017). However, PWDs at the workplace are not yet been fully embraced and practiced. There are problems and negative attitudes towards PWDs at the workplace (Maja et al., 2011; Saxena, 2014). But through education, training and government support, the improvement in the inclusion and welfare for PWDs are within reach (Tacadao and Narido, 2016). In line with these, an in-depth understanding about PWDs' inclusivity at the workplace is needed through consultations with organizations having direct engagement with them, so that the provisions and development of further programs will be given emphasis to. Moreover, it is of crucial significance to formulate a multi-sectoral approach for future research about this issue (Tacadao \& Narido, 2016). Thus, this study conducts a practical and political investigation on PWDs' inclusivity and accommodation in the context of work.

This study aims to understand the dynamics and perspectives of organizations regarding the inclusion and accommodation of persons with disabilities at the workplace within the bounds of hiring, retention, and practical and policy strategies. It seeks to answer the following questions:

1. Is there a significant relationship between the disability types of the employed PWDs and the features of the employing organizations, such as the number of organizations per province, nature of the working environment, and job titles of the employed PWDs?

2. What are the top reasons why employers do not hire and retain workers with disabilities?

3. What are the practical and political strategies supported by the public related to the hiring and retaining of workers with disabilities?

4. What will the results of this study suggest in terms of barriers and solutions in PWDs hiring? 


\section{Methods}

This study is a mixed-method sequential transformative research which is based on the collection of data and the integration of interpretations. This allows the researchers to give voice from diverse perspectives, better advocate for the participants, and better understand a phenomenon or process (Creswell, 2014). In this study, the data were gathered through surveys, focused group discussions, and interviews. The authors made use of the research documents from different literatures and sources in the conceptualization of this study. Validated instruments and tools are also utilized to gain verifiable and credible information. Consultations were carried out as to the application of industry mapping and profiling of those organizations which have directly engaged in PWDs' inclusivity and accommodation. Such organizations are located in the provinces of Aurora, Bataan, Bulacan, Nueva Ecija, Pampanga, Tarlac and Zambales, Central Luzon, Region 3, the Phillipines. PWDs here are defined as qualified workers working at places where reasonable accommodation conditions are provided and PWDs perform their essential functions at their positions as they hold or desire (National Center for Disability Affairs, 20202)). As a result, 98 organizations represented by 82 Human Resource Officers and 16 Managers participated in an in-depth mapping and a series of consultations. The total number of employed PWDs working at the 98 organizations is 161 . Organizations from the provinces of Pampanga (26\%), Zambales (22.4\%), and Nueva Ecija (16\%) show higher percentage of PWDs inclusion or reasonable accommodations. These figures are related to the economic development in those regions. In Pampanga and Zambales, for example, special economic zones and business hubs are established, while Nueva Ecija is the rice granary of the Philippines. The advantage in economic growth generates more jobs and livelihood opportunities (Business World, 2018). The numbers of organizations per province are as follows:

Table 1 Number of Organizations per Province

\begin{tabular}{|c|c|c|}
\hline Provinces & Number & \% \\
\hline Aurora & 8 & 8.2 \\
Bataan & 9 & 9.2 \\
Bulacan & 10 & 10 \\
Nueva Ecija & 16 & 16 \\
Pampanga & 25 & 26 \\
Tarlac & 8 & 8.2 \\
Zambales & 22 & 22.4 \\
\hline Total & $\mathbf{9 8}$ & $\mathbf{1 0 0}$ \\
\hline
\end{tabular}

Table 2 shows the profile of the organizations in terms of the Nature of Working Environment (2-a), Types of Disabilities (2-b), and Job Titles (2-c) of the employed PWDs. 
Table 2-a Nature of Working Environment

\begin{tabular}{|l|c|c|}
\hline Nature of Work Environment & Number & $\mathbf{\%}$ \\
\hline Manufacturing & 17 & 17.3 \\
Local Government & 14 & 14.3 \\
Distribution Selling & 12 & 12.2 \\
BPO & 7 & 7.1 \\
Manpower Services & 7 & 7.1 \\
Production & 5 & 5.1 \\
Food Services & 5 & 5.1 \\
Lending & 5 & 5.1 \\
Banking & 4 & 4.1 \\
Consultancy & 4 & 4.1 \\
Hotel Casino & 3 & 3.1 \\
Logistic & 3 & 3.1 \\
Health Wellness & 3 & 3.1 \\
Contractor (Engineering) & 2 & 2 \\
Theme Recreation & 1 & 2 \\
Hospital & 1 & 1 \\
School & $\mathbf{9 8}$ \\
Foundation & 1 & 1 \\
Security & 2 \\
Transportation & 1 \\
\hline Total & 3 & 1 \\
\hline
\end{tabular}


Table 2-b Types of Disabilities

\begin{tabular}{|l|c|c|}
\hline Type of Disabilities & Number & $\mathbf{\%}$ \\
\hline Orthopedic & 64 & 40 \\
Deaf-Mute & 29 & 26.5 \\
Visually Impaired & 6 & 3.7 \\
Psychosocial & 4 & 2.5 \\
Speech & 3 & 2 \\
Polio & 3 & 2 \\
Dwarfism (Little People) & 3 & 2 \\
Chronic Illness & 2 & 1 \\
Hearing Impaired & 1 & 0.6 \\
Cross-eyed & 1 & 0.6 \\
Muscular Disability & 1 & 0.6 \\
Congenital Bone Deformity & 1 & 0.6 \\
Inborn Fingerless & $\mathbf{1 6 1}$ & $\mathbf{1 0 0}$ \\
\hline Total & & \\
\hline
\end{tabular}

Table 2-c Job titles

\begin{tabular}{|l|c|c|}
\hline Job Titles & Number & $\mathbf{\%}$ \\
\hline Office Staff & 32 & 19.9 \\
Admin Clerk & 24 & 14.9 \\
Massage therapist & 24 & 14.9 \\
Customer Service Representative & 21 & 13 \\
Manufacturing Personnel & 14 & 8.7 \\
Production Operator & 10 & 6.2 \\
Assembly Staff & 9 & 5.7
\end{tabular}




\begin{tabular}{|l|c|c|} 
Utility Personnel & 8 & 5 \\
Messenger & 3 & 1.9 \\
Machine Operator & 2 & 1.2 \\
Instructor & 2 & 1.2 \\
Accounting Staff & 1 & 0.6 \\
Secretary & 1 & 0.6 \\
Cleaner & 1 & 0.6 \\
Recruitment Staff & 1 & 0.6 \\
Dishwasher & 1 & 0.6 \\
Service Crew & 1 & 0.6 \\
Internal Security & 1 & 0.6 \\
Maintenance Staff & 1 & 0.6 \\
Cashier & $\mathbf{1 6 1}$ & $\mathbf{1 0 0}$ \\
Branch Manager & & 0.6 \\
Project Officer & 1 & \\
\hline Total & 1 & 0.6 \\
\hline
\end{tabular}

According to Table 2-a, manufacturing (17.3\%), local government (14.3\%) and distribution \& selling $(12.2 \%)$ are the three sectors which rank the top in the percentage of PWDs they hire. Transportation, security and foundation rank the bottom in this assessment item. Table 2-b shows that $40 \%$ of PWDs being employed by those organizations are orthopedic, $26.5 \%$ are deaf-mute and $17.9 \%$ are visually impaired. Among the 161 PWDs, 32 work as office staff (19.9\%), 24 as administration clerks (14.9\%), 24 as massage therapists (14.9\%), 21 as customer service representatives (13\%). Other positions show relatively low percentages.

Purposive sampling was utilized in this study. The researcher examined a population with a unit of interests and some kind of characteristics that are not common (Lund Research, 2012). In this case, organizations which have direct engagement in the inclusivity and reasonable accommodations of PWDs were targeted. Instruments used in this study were validated interview questionnaires and the Pacific ADA Center Employer Training Questionnaire through proper coordination and exchange of communications for agreement and approval. The ADA (The Americans with Disabilities Act) tool is composed of four major constructs pertaining to PWD hiring, retention, practical, and policy strategies. A 5-point scale evaluation method was used for the twenty six statements regarding PWDs hiring and retaining, with 1 referring to "I do not 
agree" to 5 for "I strongly agree". The same 5 -point rating scale was used for the 16 statements regarding the practical and policy strategies, with 1 standing for "I do not know" to 5 for "It is very helpful".

The validated interview questionnaire focuses on questions pertaining to other reasons why employers do not hire and retain PWDs, and other practical and policy strategies suggested. The study utilized Statistical Package for Social Sciences (SPSS) version 2.0. software for generating descriptive and correlational statistics. Demographic profiles were presented through frequencies and percentages. Interview statements were checked by three experts in the fields of Human Resource, Business \& Management and Research. Before data analysis is undergone, the authors organized the data through the following processes: formulating research questions, operationalizing variables, creating a coding scheme, and quantifying the codes towards the formulation of the themes.

\section{Findings}

Findings are summarized as follows:

1. Correlations between the Types of Disabilities of Employed PWDs and the Organizations with PWD', Inclusivity per Province (3-a), Nature of Work Environment (3-b), and Job Titles (3-c) of employed PWDs

Table 3 shows the correlation between the Types of Disabilities of the Employed PWDs and the Organizations with PWDs' Inclusivity per Province (3-a), the Nature of Working Environment (3-b) and Job Titles (3-c) of the employed PWDs. Fisher Exact Test was used to determine if any non-random association exists. The results reject the null hypothesis set in this study that there is no significant relationship between the Type of Disabilities of Employed PWDs and other three factors. All types of disabilities have significant association with the Organizations employing PWDs, the Nature of Working Environment and Job Titles. But the third factor is limited to visual, auditory, orthopedic, and psychosocial disabilities for the white collar category; visual, orthopedic, and psychosocial disabilities for the blue collars and visual, auditory, orthopedic, and psychosocial disabilities for pink collars.

Table 3-a Correlation between Organizations Employing PWDs and Types of Disability Amongst

\begin{tabular}{|l|c|c|c|c|}
\hline \multirow{2}{*}{ Disability Type } & $\begin{array}{c}\text { Fisher's } \\
\text { Exact Test }\end{array}$ & Cramer's V & $\mathrm{p}$ - value & Sig \\
\hline Visual & 88.31 & 0.94 & $\mathrm{P}=0.00<0.01$ & Highly Association \\
Auditory & 97.53 & 0.93 & $\mathrm{P}=0.00<0.01$ & High Association \\
Orthopedic & 84.7 & 0.96 & $\mathrm{P}=0.00<0.01$ & High Association \\
Psychosocial & 6.11 & 0.31 & $\mathrm{P}=0.00<0.01$ & Weak Association \\
Chronic Illness & 7.05 & 0.31 & $\mathrm{P}=0.00<0.01$ & Weak Association \\
Communication Disability & 2.59 & 0.18 & $\mathrm{P}=0.00<0.01$ & Very Weak Association \\
\hline
\end{tabular}


Table 3-b Correlation between Nature of Working Environment and Types of Disability Amongst Employed PWDs

\begin{tabular}{|l|c|c|c|c|}
\hline Visual & 97.58 & 0.98 & $\mathrm{P}=0.00<0.01$ & High Association \\
Auditory & 99.77 & 0.94 & $\mathrm{P}=0.00<0.01$ & High Association \\
Orthopedic & 78.3 & 0.91 & $\mathrm{P}=0.00<0.01$ & High Association \\
Psychosocial & 5.51 & 0.29 & $\mathrm{P}=0.00<0.01$ & Weak Association \\
Chronic Illness & 5.25 & 0.28 & $\mathrm{P}=0.000<0.01$ & Weak Association \\
Communication Disability & 2.89 & 0.17 & $\mathrm{P}=0.00<0.01$ & Very Weak Association \\
\hline
\end{tabular}

Table 3-c Correlation between Job Titles and Types of Disability Amongst the Employed PWDs

\begin{tabular}{|c|c|c|c|c|c|}
\hline $\begin{array}{l}\text { Clustered } \\
\text { Job Titles }\end{array}$ & Disability Type & $\begin{array}{c}\text { Fisher's } \\
\text { Exact Test }\end{array}$ & $\begin{array}{c}\text { Cramer's } \\
\text { V }\end{array}$ & $\mathrm{p}$ - value & Sig \\
\hline \multirow{6}{*}{$\begin{array}{l}\text { White } \\
\text { Collar Jobs }\end{array}$} & Visual & 32.26 & 0.48 & $\mathrm{P}=0.00<0.01$ & $\begin{array}{l}\text { Moderate } \\
\text { Association }\end{array}$ \\
\hline & Auditory & 3.92 & 0.20 & $\mathrm{P}=0.05>0.05$ & $\begin{array}{l}\text { Very Weak } \\
\text { Association }\end{array}$ \\
\hline & Orthopedic & 25.67 & 0.43 & $\mathrm{P}=0.00<0.01$ & $\begin{array}{l}\text { Moderate } \\
\text { Association }\end{array}$ \\
\hline & Psychosocial & 6.45 & 0.26 & $\mathrm{P}=0.02<0.05$ & $\begin{array}{c}\text { Weak } \\
\text { Association }\end{array}$ \\
\hline & Chronic Illness & 0.00 & 0.01 & $\mathrm{P}=0.96>0.05$ & $\begin{array}{l}\text { Very Weak } \\
\text { Association }\end{array}$ \\
\hline & $\begin{array}{l}\text { Communication } \\
\text { Disability }\end{array}$ & 2.83 & 0.18 & $\mathrm{P}=0.08>0.05$ & $\begin{array}{l}\text { Very Weak } \\
\text { Association }\end{array}$ \\
\hline \multirow{3}{*}{$\begin{array}{c}\text { Blue Collar } \\
\text { Jobs }\end{array}$} & Visual & 55.29 & 0.66 & $\mathrm{P}=0.00<0.01$ & $\begin{array}{l}\text { Moderate } \\
\text { Association }\end{array}$ \\
\hline & Auditory & 2.02 & 0.14 & $\mathrm{P}=0.16>0.05$ & $\begin{array}{l}\text { Very Weak } \\
\text { Association }\end{array}$ \\
\hline & Orthopedic & 43.40 & 0.59 & $\mathrm{P}=0.00<0.01$ & Association \\
\hline
\end{tabular}




\begin{tabular}{|c|c|c|c|c|c|}
\hline & $\begin{array}{l}\text { Psychosocial } \\
\text { Chronic Illness } \\
\text { Communication } \\
\text { Disability }\end{array}$ & $\begin{array}{l}8.71 \\
0.35 \\
1.09\end{array}$ & $\begin{array}{l}0.26 \\
0.06\end{array}$ & $\begin{array}{l}\mathrm{P}=0.01<0.05 \\
\mathrm{P}=0.56>0.05 \\
\mathrm{P}=0.31>0.05\end{array}$ & $\begin{array}{l}\text { Weak } \\
\text { Association } \\
\text { Very Weak } \\
\text { Association } \\
\text { Very Weak } \\
\text { Association }\end{array}$ \\
\hline $\begin{array}{c}\text { Pink Collar } \\
\text { Jobs }\end{array}$ & $\begin{array}{l}\text { Visual } \\
\text { Auditory } \\
\text { Orthopedic } \\
\text { Psychosocial } \\
\text { Chronic Illness } \\
\text { Communication } \\
\text { Disability }\end{array}$ & $\begin{array}{l}57.22 \\
4.21 \\
44.84 \\
8.45\end{array}$ & 0.60 & $\begin{array}{l}\mathrm{P}=0.00<0.01 \\
\mathrm{P}=0.04>0.05 \\
\mathrm{P}=0.00<0.01 \\
\mathrm{P}=0.01<0.05 \\
\mathrm{P}=0.58>0.05 \\
\mathrm{P}=0.33>0.05\end{array}$ & $\begin{array}{l}\text { Moderate High } \\
\text { Association } \\
\text { Weak } \\
\text { Association } \\
\text { Moderate } \\
\text { Association } \\
\text { Weak } \\
\text { Association } \\
\text { Very Weak } \\
\text { Association } \\
\text { Very Weak } \\
\text { Association }\end{array}$ \\
\hline
\end{tabular}

It can be noted from the results that there is a significant associations/relationship which ranges from very weak to high associations (Table 3 -a). The $p$-values are less than 0.05 level of significance between Type of Disabilities of Employed PWDs and Organizations with PWDs' Inclusivity at $p=.00<0.01$ for visual, auditory, orthopedic, psychosocial, chronic illness, and communication disability.

Types of Disability and Nature of Working Environment also reveals significant relationship which ranges from very weak to high association at $p=.00<0.01$ for visual, $p=.000<0.01$ for auditory, $p=.000<0.01$ for orthopedic, $p=.000<0.01$ for psychosocial, $p=.000<0.01$ for chronic illness, and $p=.000<0.01$ for communication disability.

Significant association is also revealed between the Types of Disability of the Employed PWDs and White Collar Job Titles, ranging from very weak to moderate association at $p=.00<0.01$ for visual, $p=.000<0.01$ for orthopedic, and $p=.02<0.05$ with psychosocial disability. On the other hand, $p$ level proves to be at $p=.050>0.05$ with auditory, $p=.96>0.01$ for chronic illness and $p=.084>0.05$ for communication disability resulting in no significant associations. Furthermore, Blue Collar Job Titles show significant association with the Types of Disability of the Employed PWDs, with $p=.00<0.01$ for visual, 
$p=.00<0.01$ for orthopedic, and $p=.011<0.05$ for psychosocial disabilities. No significant associations are available with $p=.16>0.05$ with auditory, $p=.56>0.05$ with chronic illness, and $p=.31>0.05$ with communication disabilities. Lastly, Pink Collar Job Titles establish significant associations ranging from very weak to moderate high with $p=.00<0.01$ for visual, $p=.04<0.05$ for auditory, $p=.00<0.01$ for orthopedic, and $p=.01<0.05$ for psychosocial disabilities. On the other hand, no significant associations are found for the remaining disabilities because of $p=.58>0.05$ for chronic illness and $p=.33>0.05$ for communication disability.

The results above show that the Types of Disabilities, Nature of Working Environment and Job Titles of the employed PWDs are interrelated with one another. In order to provide accommodations to PWDs, the locations of the organizations play a pivotal role. Organizations which revolutionize business growth and development have the capacity to provide large-scale employment for the minorities such as PWDs. Although the study of Boman et al. (2013) shows that the residence region had a minor impact on the employment of PWDs, it is undoubtedly accepted that firms and companies with vibrant output and positive economic growth tend to create more employment and effectively uplift public services as well as living standards (Pettinger, 2017). Generation of more job positions and livelihood opportunities is expected if the organization is a hub for economic growth and innovation with more investment. Once employment opportunities are guaranteed, job positions are attainable for PWDs. Considers must be given before hiring PWDs as to what kind of tasks they will fulfill, and what kind of roles they will play. Organizations must examine a certain criteria and requirements set by the hiring agency and assess PWDs' skills and abilities to produce quality work. The above results support the study of Boman et al. (2013) that different disabilities are potentially important factors in obtaining employment opportunities and provision of positions, and that the barriers to the employment of PWDs vary depending on the types of disability. Besides, as what is reflected in this study, the top three provinces providing reasonable accommodation and inclusion of PWDS are all regions and zones with innovative economic development. Nueva Ecija, Pampanga and Zambales are considered fast growing economy from Central Luzon (Business World, 2018; National Nutrition Council (NNC), 2015). These findings are in support of the study of Mina (2013) that a proportion of employed PWDs are in the urban areas where development and progress are in place. This study also suggests that the Types of Disability especially pertaining to visual, auditory, and orthopedic disabilities are vital information for justifying chances towards inclusivity in the work context in accordance with the need and requirement of the organizations. According to the Implementing Rules and Regulations (IRR) of Republic Act (RA) 10524 regarding equal employment for PWDs, a person shall not be discriminated based on the types of disability with regard to matters concerning all forms of employment. That is, the Type of Disability must not be a hindrance in gaining employment as long as the applicants meet the requirement for the task performance at the workplace (Sec. 6 of RA 10524, National Center for Disability Affairs, 20201)). On the other hand, psychosocial, chronic disease, and communication disabilities result in weak correlation due to the relatively small sample size in this study.

The authors also managed to talk in person with organizations employing PWDs. Although they honestly admit that the Type of Disability is part of the hindrance in making decisions for the provision of employment 
of PWDs, they are still positive that the excuses and challenges are manageable and the inclusion of PWDs is feasible if there is continuous commitment to embrace and provide opportunities to PWDs within the organizations. This agrees to the findings of Saxena (2014) that although diversity at the workplace like working with PWDs entails challenges, workplace diversity is attainable and working with different types of people is not an issue if people inside the organizations are still positive about PWDs.

The Nature of Working Environment indeed serves as a critical element for the employment of PWDs. As Sellevol (2016) pointed out, the working environment must be given consideration to make PWDs comfortable and not disabling. Rules and Regulation of RA 10524 state that there must be necessary and appropriate modification and adjustments at the workplace for PWDs towards the daily enjoyment and exercise from the perspective of human rights and fundamental freedoms. In the study of Vornholt et al. (2018), working environment and the job itself can be a barrier towards the integration of PWDs in the field of work. Although it is mentioned in rules and regulations of RA 10524 that PWDs must be given chances to incorporate themselves to different positions at the workplace, participants of the in-depth interview in this study pointed out that there are certain aspects to be considered as to what features of a job are applicable for PWDs. The Nature of Working Environment and the task performance (job title) are two different work elements but are independent and interconnected to each other. The level of a PWD's work performance is often directly connected to the nature of work assigned to the employee (Lewis, 2019). The nature of an employee's work is best defined as the type of work that he does. This can either refer to the basic daily tasks carried out as part of a job position, or other non-routine tasks that may be required by chance.

Regarding to the relationship between the types of disability and job titles, this study offers further clarity and specification. The authors divide the job titles into three types, white collars, blue collars and pink collars. White-collar jobs refer to the normal office work and other administrative positions, blue collar jobs refer to the physical or manual labor work, and pink- collar jobs refer to entertainment, sales and customer services. The work nature and the task performance are interconnected to each other.

Through an in-depth interview, the authors found out that the nature of work demands balance between the types of disability and the position to be assumed. In this study, a large percentage of work providing accommodation for PWDs is within the manufacturing and government sectors. In line with the first-hand experiences of the authors, it was further confirmed that the employers do establish guidelines with the types of disability and the work nature taken into account before providing reasonable accommodation for PWDs. In the manufacturing sector, for example, a large number of PWDs are deaf-mutes and orthopedically disabled. They are working as manufacturing and production staff. According to the employers and the HR officers, in spite of their hearing disability and orthopedic condition (use of wheelchairs), the mobility and flexibility of their other body parts, such as hands and eyes, are still in-tact. Therefore, they meet the essential requirements needed in the task performance of assembling and disassembling of products together with delivering the products from one place to another. According to the employers and HR officers interviewed, even though the hands and eyes are in-tact for the deaf-mutes, their body parts still challenge in the task performance for assembling and disassembling products pertaining to communication because some supervisors are not competent in sign language. In the local government sectors, a big portion of 
the employed PWDs are orthopedically disabled and visually impaired. They are working as office staff or handling administrative work which requires mobility. Therefore, their supervisors gave instructions on the extensive job modifications before assigning them to the office work so that less mobility is necessary. The same considerations were applied to the totally blind PWDs working as masseurs in private wellness centers. The inability of PWDs is not a big deal because the employer values the PWDs' tactile sensitivity in using their hands, which is a strong advantage for blind people obviously. Actually, PWDs show notably impressive ability in building good relationship with their customers. The employers and HR officers are satisfied with the work of the blind masseurs. The authors also witnessed the positive feedback from the customers that the blind masseurs are very polite, respectful and know how to take good care of them. This is in line with the findings of Liu (2014) that massage therapy is considered one of the principle employment avenues for visually impaired.

Not all disabilities are considered equal when it comes to employment and health issues. They are still considered barriers to workforce representation due to additional health insurance and other accommodations. The employers and HR officers observed that having developmental disability is one of the key reasons for frequent absence and poor work quality. This is the opposite of the previous findings (Picciuto, 2014). Illness and work rights go hand in hand. Employers have to take measures to properly manage employees with chronic illness (Page, 2019). In reference to communication disability, the employers and HR officers agreed that communication is a vital element they pay most attention to. This explains why communication has become an important part of recruiting requirements especially for administrative and customer-focused tasks. Hemsley et al. (2018) addresses that all people communicate to work, build relationship and seek support. If the ability to communicate is questioned, it will serve a barrier to being included in the context of work. Good communication is an essential tool in achieving productivity and maintaining strong working relationships at all levels of an organization. Employees who communicate effectively are considered a valuable asset in the organization.

Participants of the interview reached their conclusion that the employment of PWDS is not an issue. The solution is just love, respect and work accommodations which maximize their potentials in spite of disabilities. PWDs are not useless and the stereotypes are baseless. Effective placement in the employment of PWDs makes possible match between their qualifications and expectations, and the requirements of the enterprises. Almost all jobs can be performed by someone with disability, if given the right environment. Most people with disabilities can be productive and fulfill their duties. Heron (2005) pointed out that organizations must religiously conduct the job matching process. This requires useful information about the job-seekers' experience, skills, interests and general capacity. The process also requires quality information about the jobs positions, including the specific tasks to be performed, the standard of required performance, the conditions and the organizational setting under which the work is conducted. Hiring or by providing reasonable accommodations for PWDs will in return help the organizations grow and develop with innovative thinking, unique perspectives, and other significant talents to gain competitiveness (Kuligowski, 2019). PWDs do have the capacity to grow and lead the organization if the employers provide them with equal opportunities. 


\section{Employers and HR staffs' Understanding about the Hiring and Retaining of PWDs}

Table 4-a shows the top three reasons why employers do not hire PWDs. The reasons are ranked by the degree of agreement to the question "why employers do not hire workers with disabilities" through weighted mean value together with the standard deviation (SD). The most outstanding reply is that "they rarely see people with disabilities applying for jobs" with a mean score of 3.05 and SD of .817 . This is followed by

Table 4-a Hiring Reasons

\begin{tabular}{|l|c|c|c|}
\hline \multicolumn{1}{|c|}{ Hiring Reasons } & Mean & S.D. & $\begin{array}{c}\text { Verbal } \\
\text { Interpretation }\end{array}$ \\
\hline $\begin{array}{l}\text { They rarely see people with disabilities applying for } \\
\text { jobs. }\end{array}$ & 3.05 & 0.817 & Agree \\
\hline $\begin{array}{l}\text { They are concerned about the extra time that supervi- } \\
\text { sors or co-workers will need to spend to assist workers } \\
\text { with disabilities. }\end{array}$ & 2.59 & 0.872 & Disagree \\
\hline $\begin{array}{l}\text { They can't ask about a job applicant's disability, making } \\
\text { it hard to assess whether the person can do the job. }\end{array}$ & 2.57 & 0.786 & Disagree \\
\hline $\begin{array}{l}\text { They are worried about the cost of providing "reason- } \\
\text { able accommodations" so that workers with disabilities } \\
\text { can do their jobs. }\end{array}$ & 2.53 & 0.965 & Disagree \\
\hline $\begin{array}{l}\text { They are concerned about attitudes of co-workers to- } \\
\text { ward the person with a disability. }\end{array}$ & 2.52 & 0.966 & Disagree \\
\hline $\begin{array}{l}\text { They don't know how to handle the needs of a worker } \\
\text { with a disability on the job. }\end{array}$ & 2.46 & 0.802 & Disagree \\
\hline $\begin{array}{l}\text { They are afraid that workers with disabilities won't work } \\
\text { up to the same standards as other employees. }\end{array}$ & 2.39 & 0.938 & Disagree \\
\hline $\begin{array}{l}\text { They find that job applicants with disabilities don't have } \\
\text { the necessary skills and experience. }\end{array}$ & 2.34 & 0.896 & Disagree \\
\hline $\begin{array}{l}\text { They are afraid they won't be able to discipline or fire a } \\
\text { worker with a disability for poor performance, because } \\
\text { of potential lawsuits. }\end{array}$ & 2.22 & 0.891 & Disagree \\
\hline $\begin{array}{l}\text { They are worried about other costs, such as increased } \\
\text { health insurance or worker's compensation premiums. }\end{array}$ & 2.17 & 0.953 & Disagree \\
\hline $\begin{array}{l}\text { They believe that people with disabilities can't do the } \\
\text { basic functions of the jobs they apply for. }\end{array}$ & 2.11 & 0.848 & Disagree \\
\hline $\begin{array}{l}\text { They discriminate against job applicants with disabili- } \\
\text { ties. }\end{array}$ & 2.06 & 0.917 & Disagree \\
\hline $\begin{array}{l}\text { They find that job applicants with disabilities don't } \\
\text { present themselves well in interviews. }\end{array}$ & 2.01 & 0.99 & Disagree \\
\hline $\begin{array}{l}\text { They think of workers with disabilities as "problem em- } \\
\text { ployees." }\end{array}$ & 1.91 & 0.909 & Strongly Disagree \\
\hline & 2.35 & 0.064 & Disagree \\
\hline
\end{tabular}


Table 4-b Retention Reasons

\begin{tabular}{|c|c|c|c|}
\hline Retention Reasons & Mean & S.D. & $\begin{array}{c}\text { Verbal } \\
\text { Interpretation }\end{array}$ \\
\hline $\begin{array}{l}\text { They are concerned about attitudes of co-workers to- } \\
\text { ward the worker with a disability. }\end{array}$ & 2.43 & 0.837 & Disagree \\
\hline $\begin{array}{l}\text { They can't ask about a worker's disability, making it } \\
\text { hard to assess whether the person can still do the job. }\end{array}$ & 2.27 & 0.819 & Disagree \\
\hline $\begin{array}{l}\text { They are worried about the cost of providing "reason- } \\
\text { able accommodations" so that workers with disabilities } \\
\text { can do their jobs. }\end{array}$ & 2.27 & 0.903 & Disagree \\
\hline $\begin{array}{l}\text { They don't know how to handle the needs of a worker } \\
\text { with a disability on the job. }\end{array}$ & 2.24 & 0.813 & Disagree \\
\hline $\begin{array}{l}\text { They are afraid that workers who develop disabilities } \\
\text { will become a liability to them. }\end{array}$ & 2.24 & 0.874 & Disagree \\
\hline $\begin{array}{l}\text { They are worried about other costs, such as increased } \\
\text { health insurance premiums. }\end{array}$ & 2.22 & 0.891 & Disagree \\
\hline $\begin{array}{l}\text { Workers who develop disabilities prefer not to return to } \\
\text { work. }\end{array}$ & 2.11 & 0.994 & Disagree \\
\hline $\begin{array}{l}\text { They believe that workers who develop disabilities can } \\
\text { no longer do the basic functions of their jobs. }\end{array}$ & 2.06 & 0.744 & Disagree \\
\hline $\begin{array}{l}\text { They think that workers who are poor performers only } \\
\text { get worse once they acquire a disability. }\end{array}$ & 2.01 & 0.879 & Disagree \\
\hline $\begin{array}{l}\text { They believe that workers who develop disabilities be- } \\
\text { come less dependable. }\end{array}$ & 2 & 0.76 & Disagree \\
\hline $\begin{array}{l}\text { They think of workers who develop disabilities as "prob- } \\
\text { lem employees." }\end{array}$ & 1.91 & 0.838 & Strongly Disagree \\
\hline $\begin{array}{l}\text { They believe that workers who develop disabilities be- } \\
\text { come less dedicated to their jobs. }\end{array}$ & 1.79 & 0.75 & Strongly Disagree \\
\hline OVERALL & 2.13 & 0.073 & Disagree \\
\hline
\end{tabular}

"they are concerned about the extra time that supervisors or co-workers will need to spend to assist workers with disabilities" with a mean score of 2.59 and SD of .872. The third one is "they can't ask about a job applicant's disability, making it hard to assess whether the person can do the job" with a mean score of 2.57 and SD of .786. The employers and the HR staffs disagree that they have the concerns that they have to spend extra time to take care of the PWDs. They are also willing to communicate more with the PWDs regarding their qualifications and interests so that desirable job match can be realized.

The findings above show that PWDs are not motivated enough in job-seeking, although many of them are skilled and capable. They show relatively low self-esteem and strong feeling of inferiority. They tend to assume that they are rejected by the society. Ohikuare (2018) explains the challenges PWDs have in job-seeking, the ability to apply for jobs, mobility issues, and potential prejudice by the hiring companies. In addition, Loprest and Maag (2001) further explored the reason why PWDs are discouraged from looking 
for work and discovered that there are few appropriate jobs available in line with disability they have. From our study, we come to the conclusion that organizations and HR staffs are willing to accept PWDs at their workplaces. The participants of our interview show credible and confident stand on the inclusivity of PWDs with active participation, experience, and involvement.in the work context.

Table 4-b shows the top three reasons why employers do not retain workers with disabilities. The reasons are ranked by the degree of agreement to the question "why employers do not retain workers with disabilities" through weighted mean value together with the standard deviation (SD). The very top reason is that "they are concerned about attitudes of co-workers toward the worker with a disability" with a mean score of 2.43 and SD of .837, followed by "they can't ask about a worker's disability, making it hard to assess whether the person can still do the job" with a mean score of 2.27 and SD of .819. "They are worried about the cost of providing reasonable accommodations so that workers with disabilities can do their jobs" ranks the third with a weighted mean of 2.27 and SD of .903.

Participants of the survey show disagreement to all of the three statements. This indicates that they are not in agreement or have reservation with the mentioned reasons. Because the participants have first-hand engagement in hiring and retaining of workers with disability, their answers imply that PWDs inclusivity and experience are embedded in their organizational policy and program. Employers who have committed to the inclusion and diversity issue are not prone to negative attitudes pertaining to how they see and deal with workers with disabilities (Maja et al., 2011). On the contrary, if organizations are not open for the inclusion and accommodation of PWDs, there must be fears that PWDs are costly or expensive (Kaye, Jans and Jones, 2011). The cost of accommodations serves as a critical element that needs to be addressed, not to mention the facilities and additional benefits. For this reason, it is important that multi-level stakeholders should work together especially through the help and support of the government to get rid of barriers in the employment of PWDs (Bruyere et al., 2004).

\section{Effectiveness of Practical and Policy Strategies}

Table 5 shows the top three effective practical strategies ranked by the participants regarding the hiring and retaining of workers with disability. All practical strategies are evaluated through weighted mean together with the standard deviation (SD). The very top one is "written guidelines dealing with workers with disability" with a mean score of 3.7 and SD of .578, followed by "more or better training on disability issues for supervisors and managers" with a mean score of 3.65 and SD of .611. "A written company policy of non-discrimination that includes disability" ranks the third with a mean score of 3.61 and SD of .741.

The participants of the survey evaluated all of the three strategies as "somewhat helpful". This suggests that the proposed strategies are necessary and useful in the hiring and retaining of workers with disabilities. Written company policies on non-discrimination will serve as a guiding tool that establishes a foundation of mutual respect and eliminates potential liability concerning employment practices (Mayhew, 2019). Through a written guideline dealing with workers with disability, employees are provided standards in enhancing right conduct and harmonious relationship that promote the acceptance and understanding of the employee diver-

sity issue. Aside from company policy and written guidelines regarding non-discrimination, more training 
Table 5 Practical Strategies

\begin{tabular}{|l|c|c|c|}
\hline \multicolumn{1}{|c|}{ Practical Strategies } & Mean & S.D. & Verbal \\
& & & Interpretation \\
\hline Written guidelines dealing with workers with disability. & 3.7 & 0.578 & Somewhat helpful \\
\hline $\begin{array}{l}\text { More or better training on disability issues for supervi- } \\
\text { sors and managers. }\end{array}$ & 3.65 & 0.611 & Somewhat helpful \\
\hline $\begin{array}{l}\text { A written company policy of non-discrimination that } \\
\text { includes disability. }\end{array}$ & 3.61 & 0.741 & Somewhat helpful \\
\hline $\begin{array}{l}\text { An organization-wide system for handling requests for } \\
\text { reasonable accommodations. }\end{array}$ & 3.52 & 0.749 & Somewhat helpful \\
\hline $\begin{array}{l}\text { External resources to get guidance on disability and ac- } \\
\text { commodation issues. }\end{array}$ & 3.47 & 0.735 & Somewhat helpful \\
\hline A diversity specialist who deals with disability issues. & 3.45 & 0.775 & Somewhat helpful \\
\hline $\begin{array}{l}\text { A central organization-wide source for expertise on ac- } \\
\text { commodation issues. }\end{array}$ & 3.4 & 0.822 & Somewhat helpful \\
\hline $\begin{array}{l}\text { A centralized fund within the organization to pay for } \\
\text { job accommodations. }\end{array}$ & 3.38 & 0.856 & Somewhat helpful \\
\hline \begin{tabular}{l} 
OvERALL \\
\hline
\end{tabular} & $\mathbf{3 . 5 2}$ & $\mathbf{0 . 0 9 6}$ & Somewhat \\
helpful
\end{tabular}

on disability issues for supervisors and managers is also beneficial. Managers and supervisors are expecting trainings on issues of disability, acceptance, commitment, support, and enhancement of communication skills to revolutionize awareness and eradicate discrimination (Baker and Moon, 2008). Company policy and guidelines, capability training, as well as organization-wide consultations are important strategies to consider for the improvement of the management's commitment to disability (Clark, 2013). These will further result in the development of an overall progressive and inclusive working environment that assures an appreciation of employee diversity (Bruyere et al., 2004). By working as one team together with the multi-sectoral approach, workplace accommodations and inclusions will be better understood, valued and hoped to dismantle employment discrimination and stereotypes regardless of the challenges (Dike, 2013).

Table 6 shows the top three policy strategies based on the rating of the survey participants regarding the hiring and retaining of workers with disabilities. All policy strategies are ranked through weighted mean together with the standard deviation (SD). The very top policy strategy is "a trial employment period for workers with disabilities" with a mean score of 3.4 and SD of .756, followed by "a government program to pay for or subsidize reasonable accommodations for workers with disabilities, including equipment and any needed help with job-related tasks" with a mean score of 3.39 and SD of .869. The third one is "salary subsidies for workers with disabilities" with a mean score of 3.35 and SD of .839.

Participants of the survey evaluated all of the three policy strategies as "somewhat helpful". This means that these policies will be beneficial in promoting the personal welfare of PWDs in the context of employment. Indeed, a multilevel approach is in urgent need in accommodating employees with disabilities (Bruyere et 
Table 6 Policy Strategies

\begin{tabular}{|l|c|c|c|}
\hline \multicolumn{1}{|c|}{ Practicy Strategies } & Mean & S.D. & $\begin{array}{c}\text { Verbal } \\
\text { Interpretation }\end{array}$ \\
\hline A trial employment period for workers with disabilities. & 3.4 & 0.756 & Somewhat helpful \\
\hline $\begin{array}{l}\text { A government program to pay for or subsidize reason- } \\
\text { able accommodations for workers with disabilities, in- } \\
\text { cluding equipment and any needed help with job-related } \\
\text { tasks. }\end{array}$ & 3.39 & 0.869 & Somewhat helpful \\
\hline Salary subsidies for workers with disabilities. & 3.35 & 0.839 & Somewhat helpful \\
\hline $\begin{array}{l}\text { An easy way to recruit applicants with disabilities to fill } \\
\text { vacant jobs. }\end{array}$ & 3.33 & 0.871 & Somewhat helpful \\
\hline $\begin{array}{l}\text { An externally facilitated problem-solving group to ad- } \\
\text { dress issues of accommodation and retention. }\end{array}$ & 3.22 & 0.868 & Somewhat helpful \\
\hline $\begin{array}{l}\text { Someone to come in and help solve disability - and } \\
\text { accommodation-related issues, without cost to the em- } \\
\text { ployer. }\end{array}$ & 3.21 & 0.966 & Somewhat helpful \\
\hline $\begin{array}{l}\text { An external mediation service to help resolve disability } \\
\text { and accommodation issues without recourse to lawsuits. }\end{array}$ & 3.18 & 0.923 & Somewhat helpful \\
\hline $\begin{array}{l}\text { Tax breaks for hiring or retaining workers with disabil- } \\
\text { ities. }\end{array}$ & 3.17 & 1.026 & Somewhat helpful \\
\hline \multicolumn{1}{|c|}{ OvERALL } & 3.52 & 0.096 & Somewhat \\
helpful
\end{tabular}

al., 2004; Dike, 2013). The government, for example, as one of the stakeholders, plays a very important role in providing policy strategies to which all organizations are expected to adhere to support workers with disabilities. Salary subsidies, external mediation services and individual experts are indispensable to the support to PWDs. Hopefully they can help solve the issues and reduce the concerns without extra cost of the employers and the hiring organizations. Trial employment period for workers with disabilities is also a good strategy to consider. It gives employees the opportunity to see if they can fit into their roles at the workplace and the culture there, which may reduce the hiring risks of the organizations (Stringfellow, 2019). The Multi-stakeholder approach on the mentioned strategies above is definitely needed, especially in designing and formulating an effective rule concerning financial and employment assistance to PWDs. All stakeholders must work hand in hand, as what Dike (2013) suggested that various sectors like industries, schools, government and non-governmental organizations should get involved in the program to help PWDS enhance their skills and qualifications, and improve their life quality. Such programs and policies for PWDs are expected to build a massive approach to eradicate discrimination and embrace diversity at workplaces.

\section{Employers' Perspective}

Consolidated responses and comments collected from the interview offer reasons given by the employers why they do not hire PWDs. Table 7 explains reasons for the hesitation of employers in hiring PWDs and 
retaining PWDs, and proposes practical strategies and policy strategies which are expected to solve this issue.

Based on the responses above, we summarize the reasons for the employers' hesitation in hiring and retaining PWDs:

Table 7 Consolidated Responses from Formulated Interview

\begin{tabular}{|c|c|}
\hline $\begin{array}{l}\text { Reasons for Hesitation in Hiring } \\
\text { and Retaining PWDs }\end{array}$ & $\begin{array}{l}\text {-Lack of necessary skills and abilities amongst PWDs (Inability to deal } \\
\text { with the needs of PWDs); } \\
\text { ·Poor productivity and work quality; } \\
\text { ·Employers and employees are not well equipped in dealing with the } \\
\text { needs of PWDs; } \\
\text { ·Low trust and confidence for PWDs due to direct discrimination; } \\
\text {-Additional cost to the company to hire PWDs; } \\
\text { ·High risk and maintenance in terms of safety and health; } \\
\text {-Poor awareness advocacy on inclusivity and accommodation of PWDs } \\
\text { at the workplace; } \\
\text {-Few employment opportunities and PWDs applicants for jobs; } \\
\text {-No inclusivity-friendly rules. } \\
\text {-Employers' dissatisfaction towards PWDs }\end{array}$ \\
\hline Expected Practical Strategies & $\begin{array}{l}\text { - Capacity building for PWDs through training; } \\
\text {-Formulation of guidelines and policy regarding inclusivity inside the } \\
\text { organizations; } \\
\text {-Education for employers and employees concerning inclusivity; } \\
\text {-Enhancement of inclusivity awareness across organizations on the ac- } \\
\text { commodation of PWDs; } \\
\text {-Establishment of support and administration offices within organiza- } \\
\text { tions; } \\
\text {-Partnership between government and organizations through advocacy of } \\
\text { inclusion and recognitions of PWDs, additional tax breaks and creation } \\
\text { of more job opportunities. }\end{array}$ \\
\hline Expected Practical Strategies & $\begin{array}{l}\text { - Ratification of existing laws for improvement of the discrimination issue; } \\
\text {-Mandatory inclusion and accommodation of PWDs at the workplace; } \\
\text {-Collaboration of government and industry to formulate an effective hir- } \\
\text { ing and retaining programs for PWDs; } \\
\text {-Government subsidies or financial assistance; } \\
\text {-Free education and training for PWDs; } \\
\text {-Thorough implementation of inclusivity awareness programs nation- } \\
\text { wide; } \\
\text {-Mandatory implementation of inclusivity education programs to orga- } \\
\text { nizations; } \\
\text {-Establishment of support offices for the issue and renew of permits and } \\
\text { license; } \\
\text {-Tax deduction } \\
\text {-Creation of job and livelihood opportunities for PWDs }\end{array}$ \\
\hline
\end{tabular}


(1) Lack of Awareness

Participants of the survey viewed the low awareness of PWDs inclusivity as a barrier for the promotion of the hiring and retaining issue. Due to this factor, PWDs lose commitment and support from their employers. In addition, it manifests the misconception and stereotype of people that PWDs are poor job performers. They create social discomfort and are viewed as being absent from work frequently and incompetent in task performance due to their poor health conditions. This result agrees to the study of Maja et al. (2011) that the negative attitudes toward disabled people from their fellow employees prevent the development of the current situation.

(2) Additional Cost

Potential expenses of accommodating PWDs are also considered a major factor for the issue. Workplace accessibility, work stations restructuring, extra health compensation and accommodation premiums are the major concerns and financial burdens that employers foresee. These results support the findings of Kaye, Jans and Jones (2011) that employers often see the accommodation of PWDs entail substantially large cost. Due to this reason, employers may avoid hiring and retaining PWDs to maintain profits.

(3) Incompetency of PWDs

Participants of the survey consider the lack of necessary skills and abilities of PWDs one of the reasons for their hesitation. Due to physical limitations and medical care needs brought about by disability, the proximity to gain and sustain employment is not within reach (Quilalang, 2019). There is a preconceived notion about PWDs that such their disabilities affect the quality of their task performance.

(4) Lack of Institutional Inclusivity Policy

The employers commented in the survey that the institutional policy on inclusivity of PWDs amongst organizations is not established and well-equipped. This is supported by Vornholt et al. (2018) that PWDs often fail to stay in an organization for a sustained period of time because of the lack of access to supports and assistance at the workplace. The majority of organizations do have recruiting programs but most of them are not open for PWDs, because there is no policy in place.

(5) Productivity Loss

Employers agree that poor work quality and compromised working standards have to be considered in case PWDs are employed at the workplace. Disabilities and limitations in the task performance of task may prevent PWDs from achieving the expected output of the organizations, and many organizations seldom accept any form of deviating behaviour related to productivity (Vornholt et al, 2018).

\section{Suggestions}

We make the following proposals as measures which should be taken to solve the problems with PWDs inclusivity and accommodation at the workplace:

(1) Financial Support and Subsidies

Financial support and subsidies from the government are crucial instrument in removing the barriers for the hiring and retaining of PWDs. Tacadao and Narido (2016) pointed out that governmental organizations 
play an important role in ensuring positions for PWDs at the workplace. Participants of our survey also view policies on financial assistance by the government through various incentive programs are significant strategies to consider. This will greatly reduce the concern of employers for additional costs in hiring and retaining PWDs.

(2) Capability Building

Capability building for workers with disabilities, co-employees and employers not only encourages workplace effectiveness and efficiency, but also serves as a vital strategy to better understand respect and value diversity. Participants of our survey agree that workers with disabilities must be given opportunity for further professional growth to realize their sense of value in life. Tacadao and Narido (2016) cited in their study that training and education align with capability building for PWDs are a critical factor in helping PWDs obtain satisfactory job positions. In addition, through capacity building within the context of inclusivity, co-employees and employers will be given a clear understanding to embrace diversity at the workplace and make efforts to build effective communication and harmonious working relationships with one another. Free education for PWDs is recommended by survey participants either through grants or scholarships that will establish the foundation for their competitive career advancement and growth.

(3) Institutional Inclusivity Policy

Institutional inclusivity policy across organizations is suggested by our participants to further monitor and guarantee the welfare of PWDs at the workplace. Concrete action plans could be the establishment of inclusivity support groups inside organizations and the enhancement of the guidelines and framework in handling the needs of workers with disabilities. The positive attitude and full engagement of the employers are prerequisites for successful inclusion of PWDs at the workplace. Employers' leadership may result in changes and improvement of the daily practice in serving workers with disabilities (Bruyere et al., 2004; Vornholt et al., 2018).

(4) Partnership

Government and private institutions must work hand in hand in the formulation of programs and policies regarding the inclusivity and reasonable accommodation of PWDs. Success will be achieved if there is a joint force getting involved in the project and providing chances for PWDs (Clark, 2013). Remarks and advice from experts outside the organizations should be valued. Their assistance and guidance on the matter will empower the employers and equip them with more courage in decision-making pertaining to the issue.

(5) Improvement of Anti-Discrimination Law

Improvement of anti-discrimination law is also suggested by the participants through mandatory considerations of the hiring of PWDs from the perspective of a legal and security policy. By having clear policies on inclusion, employers and PWDs fulfil responsibilities and duties respectively at the workplace through strict implementation of laws. On one hand, PWDs are confident in their security due to stipulation in the laws. On the other hand, this strategy could also reduce employer's concerns for possible lawsuits from workers with disabilities.

The present law in the Philippines states that the inclusion of PWDs at the workplace in the private sector is encouraged. However, the participants of our survey suggest that a mandatory compliance of all 
organizations, whether private or public, uphold and adhere to the promotion of inclusivity and accommodation for PWDs. More inclusively bound employment opportunities should be generated for PWDs, not just simply job positions, but jobs that cater the unique skills and abilities PWDs do have with satisfactory work environment. For PWDs, employment is particularly important because having a disability often refers to being socially isolated (WHO, 2011). Being employed is one opportunity to reduce their isolation and an important tool to reduce poverty (Schur, 2002; Vornholt et al., 2018). Work remains important and meaningful for PWDs and keeps their health condition over time (Saunders and Nedelec, 2014; Vornholt et al., 2018). Thus, the right of work should be protected by the law for PWDs.

\section{Conclusions}

This study explores the perspectives of various organizations with first-hand engagement in the inclusion of PWDs, and examines the issue of how to provide reasonable accommodation for PWDs and guarantee reasonable job positions for them which fit their personal competence and capability. The organizations consulted in this study are from the different provinces of Central Luzon, Region 3 in the Philippines. Organizations outside the aforementioned region, particularly those which are not open for the inclusion and accommodation of PWDs in the context of work, are not included. In sum, although there are still manifestations of discrimination and stereotyping in the inclusion of PWDs at the workplace, it is good to see that there are organizations providing inclusion and accommodation of PWDs especially in the public sectors. However, it is a long way to go in the private sectors. There are challenges and fears in regard to the employment of PWDs; but, if the government, private sectors, schools and PWDs work together, the formulation of practical and policy strategies may be promoted. Organizations should embrace this inevitable diversity and count PWDs in because they can perform their duties effectively at almost all job positions as long as the needed environment and conditions are provided.

The obstacles in the hiring and retaining of PWDs in the context of work include the lack of awareness about inclusivity, the incompetency issues amongst PWDs, extra cost, the lack of institutional inclusivity policy, and loss of productivity. Solutions suggested to boost the performance include financial support and subsidies from the government, capability building for industries and PWDs, the establishment of the institutional inclusivity policy, partnership between industry and government, and the improvement of the existing non-discrimination law.

In view of the summary of findings in this study, the following are recommended:

1) There should be a multi-level approach in dealing with the issue of hiring and retaining PWDs, which implies that schools, private sectors, government and non-government organizations and PWDs must work together as one team in designing programs and policies to facilitate PWDs' inclusivity at the workplace and dismantle discrimination and stereotypes.

2) There should be an in-tact profiling of employed PWDs as well as the industry mapping which provides the information on the inclusion and accommodation of PWDs at the workplace about the designated regions. Again, this can't be realized without the assistance of the various stakeholders. 
3) Future research may replicate this study by integrating a wider scope of participants, doing comparative and longitudinal analysis from more stakeholders, such as organizations that are not open for PWDs. The method proposed in this study may even be applied to different minority groups, such as the elderly, those who have been convicted with crimes and the indigenous individuals.

\section{Acknowledgment}

The researchers wish to convey their deepest gratitude to God as source of strength and wisdom as well as sincere appreciation to all individuals, government offices, and private institutions who offered help in the completion of this study.

\section{References}

Baker, P. M. and Moon, N., 2008. Policy Change and the Accommodating Workplace: Issues, Barriers and Opportunities. International Conference on Aging, Disability and Independence 2008 (ICADI). Amsterdam, Netherlands: IOS Press.

Boman, T., Kjellberg, A., Danemark, B. and Boman. E., 2013. "Can People with Disabilities Gain from Education? Similarities and differences between Occupational Attainment among Persons With and Without Disabilities", Work (Reading Mass). Retrieved at September 12, 2018 from https://www.researchgate.net/publication/256448373_Can_people_with_disabilities_gain_ Irom_education_Similarities_and_ditterences_between_occupationa」_attainment_among_ persons_with_and_without_disabilities/citation/download

Bruyere, S. M., Erickson, W. A. and VanLooy, S., 2004. "Comparative Study of Workplace Policy and Practices Contributing to Disability Nondiscrimination", Rehabilitation Psychology, Vol. 49, pp. 28-38. doi:10.1037/0090-5550.49.1.28.

Business World, 2018. Vibrant than Ever. Retrieved on October 5, 2019 from https: //wWw.bworldonline.com/vibrant-than-ever/?fbclid=IwAR272jLEkaxWvW9qDd-GVP_ FylGzuUSpifjmgXDtauH/npUbrFhbuDINPJs.

Clark, S., 2013. The Right to Employment for People with Disabilities: A Study on Jordan. Faculty of law, University of Oslo. Retrieved on August 12, 2018 from https://www.duo.uio.no/bitstream/handle/ 10852/35943/LenaBitar.pdf?sequence=1\&isAllowed=y.

Creswell, J. H., 2014. Research Design. Qualitative, Quantitative, and Mixed Methods Approaches. Fourth Edition. Thousand Oaks, CA: Sage. English Language Teaching. 12.40.10.5539/elt.v12n5p40.

Dietz, J. and Petersen, L. E., 2006. Diversity Management. In Ingmar Björkman, Günther Stahl (ed). Diversity Management. Handbook of Research in International HR Management, Edition: First Edition, pp.223-243. Edward Elgar Pub. Retrieved on August 13, 2018 from https://www.researchgate.net/ publication/260226223_Diversity_management.

Dike, P., 2013. "The Impact of Workplace Diversity in an Organization", Degree Program in International 
Business. Retrieved on September 2, 2018 from http://www.core.ac.uk/download/pdf/38093915.pdf. Dyson, M. A., 2017. "The Values of Workplace Diversity and Inclusion", The Voice of Job Seekers. Retrieved on August 2, 2018 from http://www.thevoicejobseekers.com/values-workplace-diversityinclusion/.

Hemsley, B., Turnbull, H., Steel, J., Bryant, L. and Brunner, M., 2018. We can Help to Improve Communication for People with Disabilities. Retrieved on October 23, 2019 from http://theconversation.com/wecan-all-help-to-improve-communication-for-people-with-disabilities-101199

Heron, R., 2005. "Job and Work Analysis", Guidelines on Identifying Jobs for Persons with Disabilities. International Labor Office. Geneva, Switzerland: ILO Publications.

Hicks, C., 2017. The Shift from Diversity to Inclusion - On the Road to Servant Leadership. Retrieved on November 10, 2018 from https://research.phoenix.edu/center-workplace-diversity-andinclusion-research/blog/shift-diversity-inclusion-road-servant.

Imperial, M. F., 2017. The Benefits of Hiring PWDs, As Told by Companies. Retrieved on August 10, 2018 from http://verafiles.org/articles/benefits-hiring-pwdstold- companies.

International Labour Organization (ILO), Conditions of Work Equality Department (Work Quality); Bureau for Employer's A Business As Unusual: Making Workplaces Inclusive for People with Disabilities. Retrieved on August 4, 2018 from https://www.ilo.org/wcmsp5/groups/public/---ed_emp/---ifp_skills/documents/ publication/wcms_316815.pdf.

Kaye, S. H., Jans, L. H. and Jones, E. C., 2011. "Why Don't Employers Hire and Retain Workers with Disabilities", Journal of Occupational Rehabilitation. Vol. 21, No. 4, pp. 526-536. Doi:10.1007/s10926-011$9302-8$.

Kuligowski, K., 2019. Why Hiring People with Disabilities is Good for Business. Retrieved on August 8, 2019 from https://www.business.com/articles/hire-disabled-people//.

Levosada, L., 2017. Employment of PWDs. Retrieved on January 2, 2019 from https://www.pwc.com/ph/ en/taxwise-or-otherwise/2017/employment-of-pwd.

Lewis, J., 2019. Nature of Work vs. Level of Work. Retrieved on October 22, 2019 from https:// smallbusiness.chron. com/nature-work-vs-level-work-33710.html.

Liu, G., 2014. "A Touch Better", Blind Masseurs. Retrieved on October 22, 2019 from http: //wWw.timeoutbeijing.com/features/Sports__Outdoors-Mind__Body/18004/A-touch-betterblind-masseurs.html?

Loprest, P. and Maag, E., 2001. Barriers to and Supports for Work among Adults with Disabilities: Results from the NHIS-D. The Urban Institute 2100 M Street, NW Washington,DC. Retrieved on September 12, 2019 at https://www.urban.org/sites/default/files/publication/61576/410107-Barriersto-and-Supports-for-Work-among-Adults-with-Disabilities.PDF.

Lund Research, 2012. Convenience Sampling. Retrieved on August 12, 2018 from http://www. dissertation.laerd.com/convenience-sampling.php.

Maja, P. A., Mann, W. M., Sing, D., Steyn, A. J. and Naidoo, P., 2011. "Employing People with Disabilities in South Africa", South African Journal of Occupational Therapy, Vol. 41, No. 1, pp 24-32. 
Manila Bulletin, 2014. Hiring PWDs good for business. Retrieved on January 2, 2019 from https://www. pressreader.com/philippines/manilabulletin/20141221/282157879598449.

Mayhew, R., 2019. The Importance of Eliminating Discrimination. Retrieved on February 6, 2019 from https://smallbusiness.chron.com/importance-eliminatingdiscrimination-60498.html.

Mina, C. D., 2013. Employment of Persons with Disabilities (PWDs) in the Philippines: The Case of Metro Manila and Rosario, Batangas. Philippine Institute for Development Studies. Retrieved on October 6, 2019 from https://dirp3.pids.gov.ph/ris/dps/pidsdps1313.pdf.

Mizunoya, S. and Mitra, S., 2013. Is There a Disability Gap in Employment Rates in Developing Countries? Retrieved from https://www.sciencedirect.com/science/article/abs/pii/ SU30b/50x12001593ondecember2,2018.

National Center for Disability Affairs (NCDA), 20201). Implementing Rules and Regulation (IRR) of RA 10524. Retrieved on March 4, 2020 from https://www.ncda.gov.ph/ disability-laws/implementing-rules-and-regulations-irr/irr-of-ra10524/?fbclid=

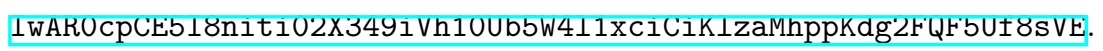

National Center for Disability Affairs (NCDA), 20202). RA 7277 - An Act Providing For the Rehabilitation, Self-Development and Self-Reliance of Disabled Person and Their Integration into The Mainstream of Society and for Other Purposes. Retrieved from https://www.ncda.gov.ph/disability-laws/republicacts/republic-act-7277/.

National Nutrition Council (NNC), 2015. Region III Profile. Retrieved on August 23, 2019 from http: //www.nnc.gov.ph/ ziamelinbe/regional-offices/region-iii-central-luzon/204-region-iii-

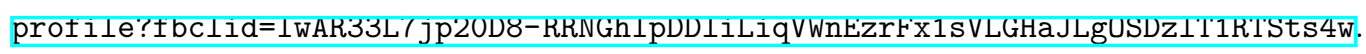

Ohikuare, J., 2018. How To Navigate Common Concerns When Job Hunting With A Disability. Retrieved on September 3, 2019 from https://www.refinery29.com/en-us/how-to-job-hunt-with-adisability.

Page, S., 2019. "Illness at the workplace: How to Support Chronically Ill Workers", Total Wellness. Retrieved on November 12, 2019 from https://info.totalwellnesshealth.com/blog/illnessattheworkplace-how-to-support-chronically-ill-workers.

Perriello, M., 2015. Ensuring Access to Long-Term Services \& Supports for People with Disabilities and Chronic Illness. Article. Retrieved on October 12, 2019 from http://www.crfb.org/sites/default/ files/perriello.pdf.

Pettinger, T., 2017. Benefits of Economic Growth. Retrieved on August 8, 2019 from https://www. economicshelp.org/macroeconomics/economic-growth/benefits-growth/.

Philippine Statistics Authority, 2010. Persons with Disability in the Philippines. Retrieved on Jan. 30, 2019 from https://psa.gov.ph/tags/persons-disability.

Picciuto, E., 2014. "Hiring People with Disabilities Isn't just the Right Thing to Do - It's Good Business", Newsletter, Daily Beast. Retrieved on November 12, 2019 from nttps: //wWw.thedailybeast.com/hiring-people-with-disabilities-isnt-just-the-right-thingto-doits-good-for-business?ref=scroll. 
Quilalang, C., 2019. Work from Home Jobs for PWDs. Retrieved on August 8, 2019 from https:// vabootcamp.ph/blog/work-from-home-jobs-for-persons-with-disability/.

Saunders, S. L. and Nedelec, B., 2014. "What Work Means to People with Work Disability: A Scoping Review", Journal of Occupational Rehabilitation, Vol. 24, pp. 100-110. doi:10.1007/s10926-013-9436-y

Saxena, A., 2014. Workforce Diversity: A Key to Improve Productivity. Simbiosis Institute of Management Studies Annual Research Conference (SIMSARC13). Retrieved on August 5, 2018 from http://creativecommons.org/license/by-nc-nd/3.0/.

Schur, L., 2002. "The Difference a Job Makes: The Effects of Employment among People with Disabilities", Journal of Economic Issues, Vol. 36, pp. 339-347. doi:10.1080/00213624.2002.11506476

Sellevol, K. S., 2016. Disability and Work Barriers to Employment: A Qualitative Study on Disability and Experiences Entering the Labor Market. Retrieved on March 10, 2020 from https://brage.inn.no/ inn-xmlui/bitstream/handle/11250/2393110/Sellevold.pdf? sequence=1\&is sllowed=y.

Stringfellow, A., 2019. Why 90-Day Trial Period Employment is Ideal for Companies: Lower Hiring Risks, the Ideal Trial Length, and More. Retrieved on February 7, 2019 from https://www.wonolo.com/blog/ 90-day-trial-employment/.

Tacadao, M. S. and Narido, S. R., 2016. Employment Research Papers WP - Employment. A Study on Employment Profile of Persons with Disabilities (PWDs) in Selected Regions in the Philippines. Retrieved on August 8, 2018 from http://ilsdole.gov.ph/a-study-on-employment-profile-of-persons-withdisabilitiespwds-in-selected-regions-in-the-philippines.

Tajfel, H., 1978. Differentiation between Social Groups - Studies in the Social Psychology of Intergroup Reations. London, UK: Academic Press.

Talent Intelligence, 2014. Inclusion and the Benefits of Diversity at the workplace. Retrieved on January 2, 2019 from http://www.talentintelligence.com/blog/bid/377611/inclusion-and-the-benefitsofdiversity-attheworkplace.

Thomas, D. A. and Ely, R., 1996. Making Differences Matter: A New Paradigm for Managing Diversity. Harvard Business Review. Retrieved on August 12, 2018 at https://hbr.org/1996/09/makingdifferences-matter-a-new-paradigm-for-managing-diversity.

Trepte, S. and Loy, L. S., 2017. Social Identity Theory and Self - Categorization Theory. Retrieved on August 12, 2018 from https://www.researchgate.net/publication/314531246.DOI:10.1002/ 9781118783764. wbieme0088.

Turner, J. C., 1999. Some Current Issues in Research on Social Identity and Self-categorization Theories. In N. Ellemers, R. Spears and B. Dossje (Eds.), Social Identity - Context, Commitment, Content (pp.6-34). Oxford, UK: Blackwell.

Unger, D. D., 2002. Employers' Attitudes toward Persons with Disabilities in the Workforce: Myths or Realities? Retrieved on November 13, 2109 from https://journals.sagepub.com/doi/abs/10.1177/ $108835 / 60201 / 00101$.

Vornholt, K., Villotti, P., Muschalla, B., Bauer, J. Colella, A., Zijlstra, F., Ruitenbeek, G. V., Uitdewilligen, S. and Corbiere, "Disability and Employment - Overview and Highlights", European Journal of Work and Organizational 
Psychology, Vol. 27, No. 1, pp. 40-55, DOI: 10.1080/1359432X.2017.1387536.

World Health Organization, 2011. World Report on Disability. Retrieved on August 1, 2019 from https: //wWw.who.int/disabilities/world_report/2011/report.pdf.

Colella, A. J., \& Bruyère, S. M., 2011. "Disability and employment: New directions for industrial and organizational psychology". In S. Zedeck (Ed.), APA Handbooks in Psychology. APA Handbook of Industrial and Organizational Psychology, Vol. 1. Building and Developing the Organization (p. 473-503). American Psychological Association. 


\title{
Appendices
}

\author{
ADA Pacific Questionnaire
}

\section{PROFILE}

* Kindly fill-out and put a tick mark (/) on the spaces being provided in which it applies.

Name of Province:

Nature of the Organization:
1) Manufacturing
2) Production
3) NPO
4) School
5) Others (Pls. Specify)

Representative:

1) Human Resource (HR \& Recruitment Staff)

2) Employer/Manager

* Number of Presently Employed Persons with Disabilities (PWDs):

\begin{tabular}{|c|c|c|}
\hline Disability Types & Number of Individual & Job title \\
\hline Deaf-mute & & \\
\hline Orthopedic & & \\
\hline Blind & & \\
\hline Chronic Illness & & \\
\hline Others (Pls. specify) & & \\
\hline & & \\
\hline
\end{tabular}

*No presently employed Persons with Disabilities (PWDs) but open for inclusion and $\begin{array}{lll}\text { accommodation: } & \text { 1) Yes } & 2 \text { ) No }\end{array}$ 


\section{HIRING \& RETENTION}

Please respond to the following statements to indicate the extent in expressing agreement from don't know to strongly agree. Please put a tick (/) mark which applies on the spaces provided.

\begin{tabular}{|c|c|c|c|c|c|c|c|}
\hline \multicolumn{3}{|l|}{ PART A } & $\begin{array}{l}\text { Strongly } \\
\text { Aoree }\end{array}$ & Agree & Disagree & $\begin{array}{l}\text { Strongly } \\
\text { Disagree }\end{array}$ & $\begin{array}{l}\text { Don't } \\
\text { Know }\end{array}$ \\
\hline \multirow{14}{*}{$\begin{array}{l}\text { Some employers } \\
\text { don't hire } \\
\text { people with } \\
\text { disabilities } \\
\text { because } \cdots\end{array}$} & 1 & $\begin{array}{l}\text { They rarely see people with } \\
\text { disabilities applying for jobs. }\end{array}$ & & & & & \\
\hline & 2 & $\begin{array}{l}\text { They find that job applicants } \\
\text { with disabilities don't have } \\
\text { the necessary skills and expe- } \\
\text { rience. }\end{array}$ & & & & & \\
\hline & 3 & $\begin{array}{l}\text { They believe that people with } \\
\text { disabilities can't do the basic } \\
\text { functions of the jobs they ap- } \\
\text { ply for. }\end{array}$ & & & & & \\
\hline & 4 & $\begin{array}{l}\text { They find that job applicants } \\
\text { with disabilities don't present } \\
\text { themselves well in interviews. }\end{array}$ & & & & & \\
\hline & 5 & $\begin{array}{l}\text { They can't ask about a job } \\
\text { applicant's disability, making } \\
\text { it hard to assess whether the } \\
\text { person can do the job. }\end{array}$ & & & & & \\
\hline & 6 & $\begin{array}{l}\text { They don't know how to han- } \\
\text { dle the needs of a worker with } \\
\text { a disability on the job. }\end{array}$ & & & & & \\
\hline & 7 & $\begin{array}{l}\text { They are worried about the } \\
\text { cost of providing "reasonable } \\
\text { accommodations" so that } \\
\text { workers with disabilities can } \\
\text { do their jobs. }\end{array}$ & & & & & \\
\hline & 8 & $\begin{array}{l}\text { They are worried about } \\
\text { other costs, such as increased } \\
\text { health insurance or worker's } \\
\text { compensation premiums. }\end{array}$ & & & & & \\
\hline & 9 & $\begin{array}{l}\text { They are concerned about at- } \\
\text { titudes of co-workers toward } \\
\text { the person with a disability. }\end{array}$ & & & & & \\
\hline & 10 & $\begin{array}{l}\text { They are concerned about the } \\
\text { extra time that supervisors or } \\
\text { co-workers will need to spend } \\
\text { to assist workers with disabil- } \\
\text { ities. }\end{array}$ & & & & & \\
\hline & 11 & $\begin{array}{l}\text { They are afraid that workers } \\
\text { with disabilities won't work } \\
\text { up to the same standards as } \\
\text { other employees. }\end{array}$ & & & & & \\
\hline & 12 & $\begin{array}{l}\text { They think of workers with } \\
\text { disabilities as "problem em- } \\
\text { ployees." }\end{array}$ & & & & & \\
\hline & 13 & $\begin{array}{l}\text { They are afraid they won't } \\
\text { be able to discipline or fire } \\
\text { a worker with a disability for } \\
\text { poor performance, because of } \\
\text { potential lawsuits. }\end{array}$ & & & & & \\
\hline & 14 & $\begin{array}{l}\text { They discriminate against job } \\
\text { applicants with disabilities. }\end{array}$ & & & & & \\
\hline
\end{tabular}


58 Count Them in! Inclusion of Persons with Disabilities in a Diversified Workforce - A Transformative Mixed-methods Study

\begin{tabular}{|c|c|c|c|c|c|c|c|}
\hline \multicolumn{3}{|l|}{ PART B } & $\begin{array}{l}\text { Strongly } \\
\text { Agree }\end{array}$ & Agree & Disagree & $\begin{array}{l}\text { Strongly } \\
\text { Disagree }\end{array}$ & $\begin{array}{l}\text { Don't } \\
\text { Know }\end{array}$ \\
\hline \multirow{12}{*}{$\begin{array}{l}\text { Some employers } \\
\text { don't hire } \\
\text { people with } \\
\text { disabilities } \\
\text { because }{ }^{\cdots}\end{array}$} & 1 & $\begin{array}{l}\text { They believe that workers } \\
\text { who develop disabilities can } \\
\text { no longer do the basic func- } \\
\text { tions of their jobs. }\end{array}$ & & & & & \\
\hline & 2 & $\begin{array}{l}\text { They believe that workers } \\
\text { who develop disabilities be- } \\
\text { come less dependable. }\end{array}$ & & & & & \\
\hline & 3 & $\begin{array}{l}\text { They believe that workers } \\
\text { who develop disabilities be- } \\
\text { come less dedicated to their } \\
\text { jobs. }\end{array}$ & & & & & \\
\hline & 4 & $\begin{array}{l}\text { They can't ask about a } \\
\text { worker's disability, making it } \\
\text { hard to assess whether the } \\
\text { person can still do the job. }\end{array}$ & & & & & \\
\hline & 5 & $\begin{array}{l}\text { They don't know how to han- } \\
\text { dle the needs of a worker with } \\
\text { a disability on the job. }\end{array}$ & & & & & \\
\hline & 6 & $\begin{array}{l}\text { They are worried about the } \\
\text { cost of providing "reasonable } \\
\text { accommodations" so that } \\
\text { workers with disabilities can } \\
\text { do their jobs. }\end{array}$ & & & & & \\
\hline & 7 & $\begin{array}{l}\text { They are worried about } \\
\text { other costs, such as increased } \\
\text { health insurance premiums. }\end{array}$ & & & & & \\
\hline & 8 & $\begin{array}{l}\text { They are concerned about at- } \\
\text { titudes of co-workers toward } \\
\text { the worker with a disability. }\end{array}$ & & & & & \\
\hline & 9 & $\begin{array}{l}\text { They think that workers who } \\
\text { are poor performers only get } \\
\text { worse once they acquire a dis- } \\
\text { ability. }\end{array}$ & & & & & \\
\hline & 10 & $\begin{array}{l}\text { They think of workers who } \\
\text { develop disabilities as "prob- } \\
\text { lem employees." }\end{array}$ & & & & & \\
\hline & 11 & $\begin{array}{l}\text { They are afraid that workers } \\
\text { who develop disabilities will } \\
\text { become a liability to them. }\end{array}$ & & & & & \\
\hline & 12 & $\begin{array}{l}\text { Workers who develop disabil- } \\
\text { ities prefer not to return to } \\
\text { work. }\end{array}$ & & & & & \\
\hline
\end{tabular}


Please respond to the following statements to indicate the extent in expressing rating from don't know to very helpful. Please put a tick (/) mark which applies on the spaces provided.

\begin{tabular}{|c|c|c|c|c|c|c|c|}
\hline \multicolumn{3}{|l|}{ PART C } & \multirow{2}{*}{$\begin{array}{l}\text { Very } \\
\text { Helpful }\end{array}$} & \multirow{2}{*}{$\begin{array}{l}\text { Somewhat } \\
\text { Helpful }\end{array}$} & \multirow{2}{*}{$\begin{array}{l}\text { Not Very } \\
\text { Helpful }\end{array}$} & \multirow{2}{*}{$\begin{array}{l}\text { Not Help- } \\
\text { ful at All }\end{array}$} & \multirow{2}{*}{$\begin{array}{l}\text { Don't } \\
\text { Know }\end{array}$} \\
\hline \multirow{8}{*}{$\begin{array}{l}\text { Employers } \\
\text { would be more } \\
\text { likely to hire } \\
\text { and retain } \\
\text { workers with } \\
\text { disabilities if } \\
\text { they had } \cdots\end{array}$} & 1 & $\begin{array}{l}\text { A written company policy } \\
\text { of non-discrimination that in- } \\
\text { cludes disability. }\end{array}$ & & & & & \\
\hline & 2 & $\begin{array}{l}\text { Written guidelines for dealing } \\
\text { with workers with disability. }\end{array}$ & & & & & \\
\hline & 3 & $\begin{array}{l}\text { More or better training on } \\
\text { disability issues for supervi- } \\
\text { sors and managers. }\end{array}$ & & & & & \\
\hline & 4 & $\begin{array}{l}\text { An organization-wide system } \\
\text { for handling requests for rea- } \\
\text { sonable accommodations. }\end{array}$ & & & & & \\
\hline & 5 & $\begin{array}{l}\text { A centralized fund within the } \\
\text { organization to pay for job ac- } \\
\text { commodations. }\end{array}$ & & & & & \\
\hline & 6 & $\begin{array}{l}\text { A central organization-wide } \\
\text { source for expertise on ac- } \\
\text { commodation issues. }\end{array}$ & & & & & \\
\hline & 7 & $\begin{array}{l}\text { External resources to get } \\
\text { guidance on disability and ac- } \\
\text { commodation issues. }\end{array}$ & & & & & \\
\hline & 8 & $\begin{array}{l}\text { A diversity specialist who } \\
\text { deals with disability issues. }\end{array}$ & & & & & \\
\hline
\end{tabular}

\begin{tabular}{|c|c|c|c|c|c|c|c|}
\hline \multicolumn{3}{|l|}{ PART D } & Very & Somewhat & Not Very & Not Help- & Don't \\
\hline \multirow{8}{*}{$\begin{array}{l}\text { Employers } \\
\text { would be more } \\
\text { likely to hire } \\
\text { and retain } \\
\text { workers with } \\
\text { disabilities if } \\
\text { there were } \cdots\end{array}$} & 1 & $\begin{array}{l}\text { Tax breaks for hiring or re- } \\
\text { taining workers with disabil- } \\
\text { ities. }\end{array}$ & & & & & \\
\hline & 2 & $\begin{array}{l}\text { Salary subsidies for workers } \\
\text { with disabilities. }\end{array}$ & & & & & \\
\hline & 3 & $\begin{array}{l}\text { A government program to } \\
\text { pay for or subsidize rea- } \\
\text { sonable accommodations for } \\
\text { workers with disabilities, in- } \\
\text { cluding equipment and any } \\
\text { needed help with job-related } \\
\text { tasks. }\end{array}$ & & & & & \\
\hline & 4 & $\begin{array}{l}\text { A trial initial employment pe- } \\
\text { riod for workers with disabil- } \\
\text { ities. }\end{array}$ & & & & & \\
\hline & 5 & $\begin{array}{l}\text { An easy way to recruit appli- } \\
\text { cants with disabilities to fill } \\
\text { vacant jobs. }\end{array}$ & & & & & \\
\hline & 6 & $\begin{array}{l}\text { Someone to come in and } \\
\text { help solve disability - and } \\
\text { accommodation-related is- } \\
\text { sues, without cost to the } \\
\text { employer. }\end{array}$ & & & & & \\
\hline & 7 & $\begin{array}{l}\text { An externally facilitated } \\
\text { problem- solving group to } \\
\text { address issues of accommo- } \\
\text { dation and retention. }\end{array}$ & & & & & \\
\hline & 8 & $\begin{array}{l}\text { An external mediation service } \\
\text { to help resolve disability and } \\
\text { accommodation issues with- } \\
\text { out recourse to lawsuits. }\end{array}$ & & & & & \\
\hline
\end{tabular}


60 Count Them in! Inclusion of Persons with Disabilities in a Diversified Workforce - A Transformative Mixed-methods Study

\section{INTERVIEW QUESTIONS:}

1. Kindly provide other reasons why some employers don't hire people with disabilities?

2. Kindly provide other reasons why some employers don't retain workers with disabilities?

3. Kindly provide any strategies that would help make employers more likely to hire and retain workers with disabilities?

4. Kindly provide any solutions, new laws or programs (policy strategies) that would help make employers more likely to hire and retain workers with disabilities?

ADA Pacific Questionnaire by H. Stephen Kaye, Ph. D. 